\title{
Jordanian University Students' Awareness of the Different Phonetic Alternates of the English Plural Morpheme
}

\begin{abstract}
This research paper investigates the extent to which Jordanian university students majoring in English are aware of the different phonetic forms or alternates of the English plural morpheme. The paper analyzes the results taken from 50 fourth-year female university students and 50 first-year female university students at Princess Alia University College at Al-Balqa Applied University in Amman. They were presented with randomized lists of 30 monosyllabic nonsense nouns selected to test their awareness of the various phonetic forms of the plural morpheme in English. The results showed that the fourth-year students outperformed the first-year students in producing the various phonetic productions of the plural morpheme. The groups used the same repair strategies. Analogy from the mother tongue was detected in the responses of both groups.
\end{abstract}

Keywords: plural morpheme, phonological forms, phonetic alternates

\section{Introduction}

The English plural regular morpheme, according to the spelling of the stem, is usually marked by the addition of either -s or -es. However, this morpheme is not always pronounced in the same way. The morpheme $-\mathrm{s}$ is sometimes pronounced as $/ \mathrm{s} /$. Other times, it is pronounced as $/ \mathrm{z} /$. In other environments, -es is pronounced as /iz/. The fact that one morpheme has different phonetic forms is usually tackled within a branch of linguistics called morphophonol- 
ogy. This branch is concerned with the interaction that takes place between phonology and morphology. Morphophonemics is defined by the Routledge Dictionary of Language and Linguistics as an intermediate level between phonology and morphology. This intermediate level describes the abstract and underlying phonological form of a morpheme that has different phonetic realizations (Bussmann, 2000).

Hence, morphophonologically speaking, the English plural morpheme -s has only one phonological representation or, as Carr (2013) refers to it, one "phonological form" (p. 115). Moreover, this phonological form is subject to the application of phonological rules and is produced in three different forms according to the neighbouring sounds - namely, the preceding sounds. The fact that this mental representation of the morpheme is subject to the application of phonological rules makes of the resulting variants predictable allomorphs or allomorphic variants of the same morpheme. Hence, English has one plural morpheme, -s, which has three different allomorphs: /s/ as in desks, /z/ as in bugs, and /iz/ as in churches.

Only one of these three phonetic forms is stored in the speaker's mental capacity as the underlying phonological form or representation. This form is the one with the widest distribution: /s/ is pronounced immediately after voiceless sounds except sibilants; /z/ is pronounced immediately after voiced sounds (consonants and vowels) except sibilants; and /iz/ is pronounced immediately after sibilants. Scrutinizing the environments in which the three allomorphs are produced, one finds that $/ \mathrm{z} /$ has the widest distribution compared to $/ \mathrm{s} /$ and $/ \mathrm{iz} /$. Consequently, we can say that in English the plural morpheme -s has one mental representation or one phonological form, namely $/ \mathrm{z} /$, which is produced as $/ \mathrm{s} /$, /z/, and /iz/ in three different environments governed by three phonological rules (Allerton, 1979). These three phonological rules, which makes their distribution complementary, are as follows:

1. $\mid \mathrm{z} / \rightarrow / \mathrm{s} /$ after voiceless sounds except sibilants.

2. $|z / \rightarrow| z /$ after voiced sounds except sibilants.

3. $/ \mathrm{z} / \rightarrow /$ iz/ after sibilants.

As we can see, the allomorphic variants of the English plural morpheme are predictable. The predictability of the distribution of these allomorphic variants is part of native speakers' linguistic knowledge. The question raised here is whether learners of English as a foreign language develop a systematic rulebased awareness of the realizations of the English plural morpheme at any stage of the learning process. In other words, do they become morphophonemically aware of the phonetic changes that take place on the plural morpheme when it is added to the stem? 


\section{Objectives}

The main goal of the current study is to investigate whether Arabic-speaking learners of English as a foreign language succeed in achieving an English proficiency level which enables them to produce the allomorphic alternates of the phonological form of the English plural morpheme in the proper environment. The current study also aims at determining which of the allomorphic variants causes difficulties for those learners. Therefore, this study is expected to contribute to the area of second language learners' morphophonological awareness of the English plural morpheme.

\section{Previous Related Studies}

The development of morphophonological awareness has attracted the attention of researchers in the field of the acquisition of English by monolingual children throughout the past decades (amongst many, Berko, 1958; Brown, 1973; Cazden, 1968). Studies on the acquisition of morphemes in general and the plural morpheme in particular were triggered by Berko's experiment conducted in 1958. This has been referred to as the Wug test, and is cited and referred to in almost every research on the acquisition of the plural morpheme and/or other morphemes in any language. In her experiment, Berko proved to adherents of structural linguistics that children apply rules to form the plural of English nouns. Not only did her experiment yield evidence for the importance of the application of rules, but it also proved children's morphophonemic awareness of the conditioned distribution of the allomorphic alternates. Her subjects were able to distinguish between the three phonetic realizations of the plural morpheme -s. They were able to produce it as $/ \mathrm{s} /, / \mathrm{z} /$, and/or /iz/ in different environments, even though they were exposed to nonsense words (Brown, 1973).

Kopcke (1998) reanalyzed Berko's results and suggested that children acquire the plural allomorphic variants starting with $/ \mathrm{s} /$ and $/ \mathrm{z} /$ and ending with /iz/.

D. Natalicio and L. Natalicio (1971) conducted a comparative research to investigate the acquisition of the English plural morpheme by English speakers and Spanish speakers. They used nonsense words. They found that the two groups' level of acquisition of the English plural morpheme was similar. They also found that both groups acquired the three English plural allomorphs in the same order. Their results were in line with Berko's (1958) and Kopcke's (1998) results in that the $/ \mathrm{s} /$ and $/ \mathrm{z} /$ allomorphs were acquired first, /iz/ being acquired at a later age. 
Al-Janaideh and Mahadin (2015) conducted a research to investigate the acquisition of the English plural morpheme by Jordanian students learning English as a foreign language. Their results showed that morphophonemic awareness is important in the development of the students' proficiency level. Their results also showed that $/ \mathrm{iz} /$ was realized shortly after realizing $/ \mathrm{s} / \mathrm{and} / \mathrm{z} /$.

Altarawneh and Hajjo (2018) also investigated Arabic university students' awareness of English plural morphemes. Their results showed that the Arabicspeaking EFL learners' level of proficiency had a little effect on their use of the plural morphemes. They attributed the students' errors to the differences between the English morphological system and the Arabic one.

Research on morphophonemic awareness and the development of the three English allomorphic variants by foreign learners of English is very rare. However, except for the Al-Janaideh and Mahadin's (2015) study, investigating the competence of the Arab learners of English in both aspects of the English inflectional plural morpheme-phonological and morphological-is also rare.

It is expected that learners of a foreign language gain a level of morphophonemic development and/or awareness. Even though this level of proficiency may vary, it is thought to be a general ability that learners develop a level of awareness at a particular stage of being exposed to the target language and its rules (Anthony \& Francis, 2005; Zeigler \& Goswami, 2005). Hence, it is important to investigate the morphophonemic awareness of Arab learners of English and to realize the kinds of problems or difficulties they face in order to try to find a way to facilitate the learning process for them. It is equally important to try to find ways to enhance the students' competence.

\section{Methodology}

\section{Subjects}

For the application of this study, 100 female Jordanian Arabic-speaking university students were tested. They were divided into two groups: 50 students were in their fourth year and 50 students were in their first year. All of them were majoring in English Language and Literature at Princess Alia University College at Al-Balqa Applied University in Amman, Jordan. All the students were monolinguals whose parents were also Jordanian speakers. All of the respondentswere selected randomly. 


\section{Procedures}

Since the purpose of this study is to test Jordanians' morphophonological awareness of the phonological conditions, which govern the distribution of the different phonetic realizations of the English plural inflectional morpheme, a list of 30 nonsense monosyllabic singular nouns was prepared for this study. These nonsense words were created in accordance with the English phonotactics, which dictates the possible combinations of sounds in English. Each of the three plural allomorphs was represented by ten of the listed words. Ten of the 30 nonsense nouns end in voiceless sounds except sibilants, which add the /s/ allomorph when pluralized. Ten of the 30 words end in voiced sounds except sibilants and add the /z/ allomorph when pluralized. In addition, the last ten words end in sibilants and add the /iz/ allomorph when pluralized. The listed words were presented to the students in a random order so that the students would not detect any pattern. Since the subjects were aware of what they were doing, being university students, there was no need to expose them to different pictures of unfamiliar objects to represent the nonsense words. Accordingly, the first researcher, who was a linguist and speech therapist, read each singular item and asked the subjects to give its plural form. Subjects were tested individually in the Language Laboratory in Princess Alia University College in the presence of the researchers. Data were recorded by digital voice recorder and transferred to the computer as a WinRAR file. The researchers transcribed the recorded data after each session to avoid any misinterpretation that could have taken place due to time lag. Transcribed data were saved in computer files.

\section{Results}

The researchers analyzed and tabulated the elicited data. Means and standard deviations of the total productions were calculated and a t-test was carried out to compare and contrast the subjects' production.

The following question was raised:

Is there any statistically significant difference at $(a=0.05)$ in the total production of (iz, s, z) due to the year variable?

To answer this question, means and standard deviations of the total production of (iz, s, z) were used and a t-test was carried out to find out any significant differences between the production of both groups. Table 1 shows the results. 
Table 1

Means, standard deviations and t-test results of the first- and fourth-year students (iz, $s, z)$

\begin{tabular}{|l|l|c|c|c|c|c|c|}
\hline $\begin{array}{c}\text { Allomorphic } \\
\text { variant }\end{array}$ & \multicolumn{1}{|c|}{ Year } & $\mathrm{N}$ & Mean & Std. Deviation & $\mathrm{t}$ & $\mathrm{df}$ & Sig. (2-tailed) \\
\hline \multirow{2}{*}{$/ \mathrm{izl}$} & First & 50 & 6.08 & 2.671 & -5.606 & 98 & 0.000 \\
\cline { 2 - 6 } & Fourth & 50 & 8.52 & 1.529 & & & \\
\hline \multirow{2}{*}{$/ \mathrm{s} /$} & First & 50 & 9.52 & .614 & -4.822 & 98 & 0.000 \\
\cline { 2 - 5 } & Fourth & 50 & 9.96 & .198 & & & \\
\hline \multirow{2}{*}{$/ \mathrm{z} /$} & First & 50 & 4.40 & 2.807 & -1.769 & 98 & 0.080 \\
\cline { 2 - 5 } & Fourth & 50 & 5.22 & 1.694 & & & \\
\hline \multirow{2}{*}{ Total } & First & 50 & 20.00 & 5.147 & -4.470 & 98 & 0.000 \\
\cline { 2 - 5 } & Fourth & 50 & 23.70 & 2.787 & & & \\
\hline
\end{tabular}

Table 1 shows that there are statistically significant differences at a $=0.05$ between the means of the first- and fourth-year students in the production of (iz) in favor of fourth-year students. The table also shows that there are statistically significant differences at $\mathrm{a}=0.05$ between the means of the first- and fourth-year students in the production of (s) in favor of fourth-year students. In addition, the table indicates no statistically significant differences at $\mathrm{a}=0.05$ between the means of the first- and fourth-year students in (z). Finally, there are statistically significant differences at $a=0.05$ between the means of the first- and fourth-year students in total in favor of fourth-year students.

\section{Discussion}

\section{First-Year Students}

Table 2 shows the overall correct productions of the allomorphic variants of the regular plural marker in percentages as produced by first-year students. Table 2

First-year students' correct responses

\begin{tabular}{|c|c|}
\hline Allomorphic Variant & $\begin{array}{c}\text { Percentage of Correct } \\
\text { Responses }\end{array}$ \\
\hline /s/ & 95.2 \\
\hline /z/ & 42.2 \\
\hline /iz/ & 60.8 \\
\hline
\end{tabular}


As can be inferred from Table 2, the production of the allomorph /s/ almost hit the ceiling, as 95.2 per cent of the total production of the /s/ allomorph was correct. Correct production of the /iz/ allomorph came next: its production scored 60.8 per cent. The $/ \mathrm{z} /$ allomorph scored only 42.2 per cent.

Table 3 shows the detailed percentages of the correct responses for each nonsense word that was used in the experiment.

Table 3

Percentages of correct responses produced by first-year students

\begin{tabular}{|l|c|c|c|c|c|}
\hline Nouns with /s/ & $\begin{array}{c}\text { Percentage } \\
\text { of correct } \\
\text { responses }\end{array}$ & Nouns with /z/ & $\begin{array}{c}\text { Percentage } \\
\text { of correct } \\
\text { responses }\end{array}$ & Nouns with /iz/ & $\begin{array}{c}\text { Percentage } \\
\text { of correct } \\
\text { responses }\end{array}$ \\
\hline throp(s) & 92 & ferd(z) & 22 & flerch(iz) & 42 \\
\hline klop(s) & 100 & tred(z) & 18 & feech(iz) & 58 \\
\hline besk(s) & 100 & skug(z) & 70 & nuce(iz) & 86 \\
\hline plock(s) & 100 & frem(z) & 78 & mace(iz) & 72 \\
\hline dat(s) & 100 & blove(z) & 70 & trize(iz) & 54 \\
\hline dight(s) & 100 & $\operatorname{lin}(z)$ & 20 & threez(iz) & 72 \\
\hline kyth(s) & 76 & san(z) & 40 & fladge(iz) & 40 \\
\hline bonth(s) & 96 & thill(z) & 22 & ladge(iz) & 44 \\
\hline bliff(s) & 100 & thribe(z) & 0 & lish(iz) & 68 \\
\hline groof(s) & 88 & stee(z) & 82 & frash(iz) & 72 \\
\hline
\end{tabular}

As far as the production of the /s/ allomorph is concerned, the subjects found no difficulty attaching the plural morpheme and producing it as the expected /s/ in the following words: *klop, *besk, *plock, *dat, *dight and *biff. The subjects' correct production of these words scored 100 per cent. The word *bonth came next, scoring 96 per cent. *Throp scored 92 per cent, followed by * groof, which scored 88 per cent. The production of *kyth scored the lowest percentage of the correct responses at 76 per cent.

With regard to production of the /iz/ allomorph, Table 3 above shows that the production of this allomorph did not go as smoothly as the production of $/ \mathrm{s} /$. None of the terms scored 100 per cent. The highest percentage that appeared in the production of words that would add the /iz/ allomorph was 86 per cent, scored by the word *nuce, while *mace, *threez and *frash scored 72 per cent. *Lish scored 68 per cent, followed by *feech and *trize, which scored 58 per cent and 54 per cent respectively. *Ladge, *flerch, and *fladge scored the lowest: the percentages of their correct production were 44 per cent, 42 per cent, and 40 per cent respectively. 
The group of words that add the /z/ allomorph scored the lowest percentages compared to the production of /s/ and /iz/. *Stee and *frem are the words with the highest percentages of correct production, as they scored 82 per cent and 78 per cent respectively. *Blove and *skug came next, both scoring 70 per cent. The correct production of *san scored 40 per cent, while *thill and *ferd scored 22 per cent each. * Lin and *tred scored 20 per cent and 18 per cent respectively, whereas no student achieved correct production of the plural of *thribe.

As can be seen from the data analysis above, the correct production of the /z/ allomorph posed a challenge to the first-year students, even though it is confirmed that it is the mental representation or the phonological form of the English plural morpheme (Carr, 2013). To put it differently, $/ z /$ is the phonological form that is associated with the plural morpheme in the linguistic knowledge of native speakers of English. Theoretically, first-year students were expected to have no difficulty producing it, especially as they had been exposed to the English language for a reasonable number of scholastic years. However, it is obvious that their competence has not fully developed yet.

With regard to production of the allomorph $/ \mathrm{z} /$, and if the last sound of the stem is taken into consideration, no particular sound at the end of the terms can be said to have caused this production problem. This is because there is a clear discrepancy between the production of words that end in the same sound. For example, although *lin and *san both end in $/ \mathrm{n} /, 80$ per cent of the overall production of *lin was incorrect, while the percentage of incorrect production of *san was 60 per cent. Looking at it from the perspective of natural classes does not work either. The term *frem ends in the bilabial nasal $/ \mathrm{m} /$; however, its incorrect production had a percentage of 22 per cent of the total production of the word. The stem with the vowel as its last segment was produced with the lowest percentage of incorrect responses $(18 \%)$, whereas the stem that ends in $/ \mathrm{b} /$ was produced incorrectly by all.

Concerning the production of the allomorph /s/, stem final sounds could not yield any justification for the errors in the students' productions. This is also because of the obvious discrepancy between the percentages scored by stems that end in the same sound. For example, although *kyth and *bonth both end in a voiceless interdental, the percentage of incorrect production of *kyth was 24 per cent, while that of *bonth was only 4 per cent. Another discrepancy could be found in the incorrect production of the terms ending in the voiceless bilabial stop. Incorrect production of the /s/ allomorph in *throp was 8 per cent, while *klop did not have any incorrect production.

This explanation also applies to the production of the /iz/ allomorph in stems ending in sibilants. Discrepancy in the production of the /iz/ allomorph was witnessed in the production of *nuce and *mace. Both end in the voiceless alveolar fricative. Nonetheless, the percentage of incorrect production of *nuce was 14 per cent, while that of *mace was 28 per cent. 


\section{Students' Repair Strategies}

It is worth noting that first-year students did not resort to deletion as a repair strategy. On the contrary, they resorted to replacement. Students' repair strategies varied and overlapped. No particular pattern in the use of the repair strategies was detected. All students' incorrect productions of the /z/ allomorph took the form of replacing /z/ with /s/. This is illustrated in Table 4.

Table 4

Students' replacement of the /z/ allomorph

\begin{tabular}{|c|c|c|}
\hline$/ s /$ & $/ i z /$ & $/ i s /$ \\
\hline $100 \%$ & $0 \%$ & $0 \%$ \\
\hline
\end{tabular}

On the other hand, students' incorrect productions of the /iz/ allomorph took the form of replacing /iz/ with either/z/, /s/ or, unexpectedly, /is/. Replacement with the non-existent /is/ was used more frequently than $/ \mathrm{s} /$ and $/ \mathrm{z} /$. This is illustrated in Table 5.

Table 5

Students' replacement of the /iz/ allomorph

\begin{tabular}{|c|c|c|}
\hline$/$ is/ & $\mid z /$ & $/ s /$ \\
\hline $62 \%$ & $17 \%$ & $21 \%$ \\
\hline
\end{tabular}

Finally, /s/ also underwent fewer instances of replacement. It was replaced by /is/, /z/ and/or/iz/. Once again, replacing/s/ with the non-existing/is/ showed the highest percentage. Table 6 illustrates the repair strategy for this allomorph.

Table 6

Students' replacement of the /s/ allomorph

\begin{tabular}{|c|c|c|}
\hline /is/ & $\mid z /$ & /iz/ \\
\hline $22 \%$ & $18 \%$ & $8 \%$ \\
\hline
\end{tabular}

Hence, first-year students did encounter problems producing the English plural allomorphic alternates. The only repair strategy that was used by the students was replacement. The replacement of the allomorphs overlapped. Students' production was not based on the phonological structure of the stem. The students' choice of the replacement for the expected allomorph was not based on the phonological structure of the stem, either. Not only did the students mix the productions of the three allomorphs of the plural, but they also created a fourth one-namely, /is/. 


\section{Fourth-Year Students}

Table 7 shows the percentages of the overall correct production of the allomorphic variants of the regular plural marker as produced by fourth-year students.

Table 7

Fourth-year students' correct responses

\begin{tabular}{|c|c|}
\hline Allomorphic variant & $\begin{array}{c}\text { Percentage of correct } \\
\text { responses }\end{array}$ \\
\hline /s/ & 99.6 \\
\hline /z/ & 52.0 \\
\hline$/ \mathrm{iz} /$ & 85.2 \\
\hline
\end{tabular}

As can be seen from Table 7, the production of the allomorph /s/ almost hit the ceiling, as 99.6 per cent of the total production of the /s/ allomorph was correct. Correct production of the /iz/ allomorph came next, scoring 85.2 per cent. The /z/ allomorph scored only 52 per cent.

Table 8 shows the detailed percentages of correct responses for each nonsense word.

Table 8

Percentages of correct responses produced by fourth-year students

\begin{tabular}{|l|c|c|c|c|c|}
\hline Nouns with /s/ & $\begin{array}{c}\text { Percentage } \\
\text { of correct } \\
\text { responses }\end{array}$ & Nouns with /z/ & $\begin{array}{c}\text { Percentage } \\
\text { of correct } \\
\text { responses }\end{array}$ & Nouns with /iz/ & $\begin{array}{c}\text { Percentage } \\
\text { of correct } \\
\text { responses }\end{array}$ \\
\hline throp(s) & 100 & ferd(z) & 26 & flerch(iz) & 82 \\
\hline klop(s) & 100 & $\operatorname{tred}(z)$ & 36 & feech(iz) & 90 \\
\hline besk(s) & 100 & skug(z) & 84 & nuce(iz) & 88 \\
\hline plock(s) & 100 & frem(z) & 94 & mace(iz) & 88 \\
\hline dat(s) & 100 & blove(z) & 86 & trize(iz) & 80 \\
\hline dight(s) & 100 & $\operatorname{lin}(z)$ & 20 & threez(iz) & 82 \\
\hline kyth(s) & 96 & $\operatorname{san}(z)$ & 38 & fladge(iz) & 84 \\
\hline bonth(s) & 100 & thill(z) & 32 & ladge(iz) & 82 \\
\hline bliff(s) & 100 & thribe(z) & 4 & lish(iz) & 86 \\
\hline groof(s) & 100 & stee(z) & 100 & frash(iz) & 90 \\
\hline
\end{tabular}

As far as the production of the /s/ allomorph is concerned, it is obvious that the subjects found no difficulty producing the allomorph /s/ correctly, as its correct production scored 100 per cent for almost all the terms, except for the production of *kyth, whose correct production scored 96 per cent. 
With regard to production of the /iz/ allomorph, Table 8 shows that the subjects of this study found difficulty producing this allomorph. None of the terms scored 100 per cent. The highest percentage scored in the production of words that add the /iz/ allomorph was 90 per cent, which was scored by *feech and *frash. *Mace and *nuce came next, as both words scored 88 per cent. *Lish and *fladge scored 86 per cent and 84 per cent respectively, while *flerch, *threez and *ladge scored 82 per cent. *Trize scored lowest among this group, with 80 per cent.

Table 8 also shows that the group of words that add the /z/ allomorph scored the lowest percentages of correct production compared to the percentages of production of $/ \mathrm{s} /$ and /iz/. All participants produced the word *stee correctly. *Frem was the word with the second highest percentage of correct production, scoring 94 per cent. *Blove and *skug came next: they scored 86 per cent and 84 per cent respectively. The correct production of *san scored 38 per cent, while *thill and *tred scored 36 per cent and 32 per cent respectively. *Ferd scored 26 per cent and *lin scored 20 per cent. The term *thribe achieved the lowest percentage of correct responses, not exceeding 4 per cent.

Even though the $/ z /$ allomorph is considered the phonological form or the mental representation of the plural morpheme in English, fourth-year subjects found real difficulty with correct production of the /z/ allomorph. As was the case with the production by the first-year students, fourth-year students' production revealed an unexpected difficulty, especially as they had not only been exposed to the English language throughout their scholastic years, but had also been majoring in English for three and a half years. They are expected to be aware of such phonotactics of the English plural morpheme. Surprisingly, their competence has not fully developed yet.

The data set elicited from the fourth-year students also shows no particular phonological reason for the problems reflected in the production of the three allomorphs. There is no relationship between the last sound of the word stem and the incorrect production of the allomorph. There is a clear discrepancy between the production of the /z/ allomorph in words that end in the same sound. For example, although *ferd and *tred end in the voiced alveolar /d/, the percentage of correct responses for *ferd was 26 per cent, while *tred had a percentage of 36 per cent. Such a discrepancy is also shown in the production of *lin and *san, which both end in the alveolar nasal stop /n/. The former scored 38 per cent, the latter 20 per cent. *Frem, which ends in the bilabial nasal stop, scored 94 per cent. This makes it difficult to justify the production problem from the perspective of the natural classes, too. All the participants produced the stem that ends in a vowel correctly. However, only two of the participants produced the stem that ends in $/ \mathrm{b} /$ correctly.

This explanation cannot be said to apply to the production of the /iz/ allomorph in stems ending in sibilants. The discrepancy in the production of the /iz/ allomorph can be said to be insignificant by virtue of the very close percentages of correct productions shown by word stems that end in the same phoneme. 
Stems ending in the voiceless fricative /s/ scored the same percentage of correct production (88\%). Stems ending in the voiceless palate-alveolar scored 90 per cent and 86 per cent. Those stems, which end in the voiced affricate, scored 82 per cent and 84 per cent. Overall, we can say that the discrepancy in the production of the allomorph /iz/ in stems that end in sibilants is negligible.

Concerning the production of the allomorph /s/, only two instances of incorrect production of $/ \mathrm{s} /$ were noticed in the word *kyth. The /s/ allomorph was replaced by /iz/. Otherwise, the participants found no problem in the production of this allomorph.

\section{Students' Repair Strategies}

The only repair strategy this group of students resorted to in the process of producing the three allomorphic variants was replacement. A slight difference was detected between the use of the only repair strategy by the two groups. Fourth-year students' incorrect production of the $/ z /$ allomorph took the form of replacing /z/ with /s/. This is illustrated in Table 9.

Table 9

Students' replacement of the /z/ allomorph

\begin{tabular}{|c|c|c|}
\hline$/ \mathrm{s} /$ & /iz/ & /is/ \\
\hline $100 \%$ & $0 \%$ & $0 \%$ \\
\hline
\end{tabular}

On the other hand, in the production of the /iz/ allomorph, students' repair strategies varied and overlapped. No particular pattern in the use of the repair strategy was detected. The production of the allomorph /iz/ took the form of replacing it with either $/ \mathrm{z} /$, /s/ or, unexpectedly, /is/. Just as for the first-year students, replacement with the non-existing /is/ was used more frequently than /s/ and /z/. This is illustrated in Table 10 .

Table 10

Students' replacement of the /iz/ allomorph

\begin{tabular}{|c|c|c|}
\hline$/$ is/ & $\mid z /$ & $/ s /$ \\
\hline $69 \%$ & $16 \%$ & $15 \%$ \\
\hline
\end{tabular}

Finally, /s/ also underwent only two instances of replacement. It was replaced by /iz/ in both instances. Table 11 illustrates the repair strategy of this allomorph.

Table 11

Students' replacement of the /s/ allomorph

\begin{tabular}{|c|c|c|}
\hline$/$ is/ & $\mid z /$ & $/ i z /$ \\
\hline $0 \%$ & $0 \%$ & $3 \%$ \\
\hline
\end{tabular}


Apparently, fourth-year students also encountered a problem with the production of the English plural allomorphic alternates. The only repair strategy that was used by the students was replacement. Replacement of the allomorphs overlapped. Students' production was not based on the phonological structure of the stem. The students' choice of replacement for the expected allomorph was not based on the phonological structure of the stem, either. Not only did the students mix the production of the three allomorphs of the plural, but they also created a fourth one-namely, /is/.

\section{Comparing the First-Years' Results to the Fourth-Years' Results}

Comparing the first-year students' to the fourth-year students' results makes it clear that the students' competence has developed to a certain degree over their university years. This is obvious in the percentages shown in Table 12. The fourth-year students outperformed the first-year students.

Table 12

Total correct responses of the two groups

\begin{tabular}{|c|c|c|}
\hline Allomorphic variant & $\begin{array}{c}\text { First-year students' } \\
\text { performance }\end{array}$ & $\begin{array}{c}\text { Fourth-year students' } \\
\text { performance }\end{array}$ \\
\hline /s/ & $95.2 \%$ & $99.6 \%$ \\
\hline /z/ & $42.2 \%$ & $52.0 \%$ \\
\hline /iz/ & $60.8 \%$ & $85.2 \%$ \\
\hline Students' total performance & $56.0 \%$ & $79.0 \%$ \\
\hline
\end{tabular}

Table 12 shows a comparison between the overall performance of the firstyear students and the fourth-year students. As can be seen in the table, there is a clear development of the students' competence regarding the different phonetic productions of the English plural morpheme. This is evident in the increased percentage of the fourth-year students' production. However, it is clear that this competence does not yet match native speakers' competence. It has not fully developed to the extent that their production is error-free.

Furthermore, Table 12 shows that in their correct responses for the three allomorphic variants, both groups scored highest in favor of /s/ followed by /iz/. The allomorph /z/ saw the fewest correct occurrences in both groups' productions. 
Although both groups encountered difficulty in producing *kyth with the proper pronunciation of the morpheme -s, the fourth-year students' production was more accurate than the first-year students.' Since *kyth was the only term which was produced incorrectly by the fourth-year students, it is fair to overlook this incorrect production.

The first-year students ran into problems with *kyth, *bonth, and *throp. The fact that the first three words end in a fricative and that $/ \mathrm{s} /$ is also a fricative led Al-Janaideh and Mahadin (2015) to attribute this kind of problem to the manner of articulation of the final sound of the nonsense words. However, this interpretation fails to account for this phenomenon in this current study, because the same group's production of *bliff scored 100 per cent. The same group erred in the production of *throp (92\%); however, they scored 100 per cent in the production of *klop.

The $/ \mathrm{z} /$ allomorph, on the other hand, scored the lowest correct responses in spite of the fact that it was expected to be produced correctly by virtue of its being the underlying phonological form of the morpheme. This is true for the production of both groups. Table 13 compares the production of $/ \mathrm{z} / \mathrm{by}$ both groups.

Table 13

The production of $\mid z /$ by both groups

\begin{tabular}{|c|c|c|c|c|c|c|c|c|c|c|}
\hline $\begin{array}{l}\text { First-Year } \\
\text { Students' } \\
\text { Production }\end{array}$ & ferds & treds & skugs & frems & bloves & zins & sans & thills & thribes & stees \\
\hline $\begin{array}{l}\text { Number of incor- } \\
\text { rect productions }\end{array}$ & 39 & 41 & 15 & 11 & 15 & 40 & 30 & 39 & 50 & 9 \\
\hline $\begin{array}{l}\text { Percentage } \\
\text { incorrect }\end{array}$ & \multirow{2}{*}{\multicolumn{2}{|c|}{78}} & \multirow[t]{2}{*}{30} & \multirow[t]{2}{*}{22} & \multirow[t]{2}{*}{30} & \multirow{2}{*}{\multicolumn{2}{|c|}{80}} & \multirow[t]{2}{*}{78} & \multirow[t]{2}{*}{100} & \multirow[t]{2}{*}{18} \\
\hline Average incorrect & & & & & & & & & & \\
\hline $\begin{array}{l}\text { Percentage } \\
\text { correct }\end{array}$ & \multirow[t]{2}{*}{22} & \multirow[t]{2}{*}{18} & \multirow[t]{2}{*}{70} & \multirow[t]{2}{*}{78} & \multirow[t]{2}{*}{70} & 20 & \multirow[t]{2}{*}{40} & \multirow[t]{2}{*}{22} & \multirow[t]{2}{*}{0} & \multirow[t]{2}{*}{82} \\
\hline Average correct & & & & & & & & & & \\
\hline $\begin{array}{l}\text { Fourth-Year } \\
\text { Students' } \\
\text { Production }\end{array}$ & ferds & treds & skugs & frems & bloves & zins & sans & thills & thribes & stees \\
\hline $\begin{array}{l}\text { Number of incor- } \\
\text { rect productions }\end{array}$ & 37 & 32 & 8 & 3 & 7 & 40 & 31 & 34 & 48 & 0 \\
\hline $\begin{array}{l}\text { Percentage } \\
\text { incorrect }\end{array}$ & \multirow[t]{2}{*}{74} & \multirow[t]{2}{*}{64} & \multirow[t]{2}{*}{16} & \multirow[t]{2}{*}{6} & \multirow[t]{2}{*}{14} & \multirow{2}{*}{\multicolumn{2}{|c|}{80}} & \multirow[t]{2}{*}{68} & \multirow[t]{2}{*}{96} & \multirow[t]{2}{*}{0} \\
\hline Average incorrect & & & & & & & & & & \\
\hline $\begin{array}{l}\text { Percentage } \\
\text { correct }\end{array}$ & \multirow[t]{2}{*}{26} & \multirow[t]{2}{*}{36} & \multirow[t]{2}{*}{84} & 94 & 86 & 20 & 38 & 32 & 4 & 100 \\
\hline Average correct & & & & & & & & & & \\
\hline
\end{tabular}


We supposed that the $/ z /$ allomorphic variant of the plural morpheme is stored mentally in the students' capacities after being exposed to the English language formally and informally. In particular, fourth-year students were expected to excel in the production of this variant, because they were expected to have developed a competence that would enable them to realize the mental representation of the plural morpheme. However, this expectation was not realized, as can be seen from the percentages in Table 13. A slight improvement can be seen in the fourth-year students' production, but it was not up to the level of expectation. As mentioned earlier, no particular pattern was detected in the students' responses. The stem which ends in a vowel had the highest percentage of correct production by both groups. The stem that ends in $/ \mathrm{b} /$, however, had the lowest percentage of correct production by both groups. Among fourth-year students, 96 per cent of production was incorrect; among first-year students, all production was incorrect. Stems ending in $/ \mathrm{d} /$ and $/ \mathrm{n} /$ witnessed poor production by members of both groups. The average percentages of incorrect responses by fourth-year students were 69 per cent and 71 per cent respectively for stems that end in $/ \mathrm{d} /$ and $/ \mathrm{n} /$. The first-year students performed less accurately. Their average percentages of incorrect responses were 80 per cent and 70 per cent respectively. The stem ending in the bilabial nasal stop scored the second lowest percentage in the production of both groups.

The fact that students in both groups tended to replace the /z/ allomorph with /s/ shows a partial agreement with Al-Janaideh and Mahadin's (2015) study. Their study showed evidence for the attachment of $/ \mathrm{s} /$ instead of $/ \mathrm{z} /$ by members of the older group rather than the younger one. They tried to justify their subjects' performance by stating that their subjects preferred using the voiceless $/ \mathrm{s} /$ after the voiced $/ \mathrm{b} /$ to using the voiced $/ \mathrm{z} /$. Our data show a tendency to replace the $/ \mathrm{z} /$ with $/ \mathrm{s} /$ among members of both groups. However, this tendency decreases in the performance of the older group.

This current study also showed that not only did almost all members of both groups prefer using /s/ to using / $/ \mathrm{z}$, but they also devoiced the last segments in *thribe, *blove, and *skug. This devoicing resulted from a kind of regressive assimilation. Regressive assimilation was also attested in Berko's (1968) experiment when her subjects voiced the final/f/ in *heaf. However, our subjects preferred to devoice final segments to assimilate them with /s/ rather than voice them.

The fact that our subjects tended to devoice stem final segments is consistent with Peng and Ann's (2004) study. Their subjects also showed a preference to devoice the stem final segment and add /s/ in the word hands, which was produced as /hants/. Their explanation for this phenomenon was based on first language interference rather than English phonological rules or phonetic similarity. This first language interference justification may also apply to our subjects' production. The reason that our students' production of $/ \mathrm{s} / \mathrm{almost}$ hit 
the ceiling and they chose to replace /z/ with /s/ could reflect interference by the students' mother tongue in the production of the English allomorphic variants. The Arabic phoneme /s/ has only one mental representation and one phonetic production [s]. Apparently, what they were producing was actually the Arabic /s/ phoneme rather than the English allomorphic variants.

As far as the /iz/ allomorph is concerned, students in both groups performed better when attaching /iz/ to stems ending in sibilants than when attaching $/ \mathrm{z} /$ to stems ending in voiced sounds.

This finding of this preference contradicts findings in previous studies. Berko (1958) posited that the plural allomorphic variant/iz/ was acquired last. She attributed this to the fact that children were dealing with these stems as if they were already in the plural form by virtue of the sort of sound with which each stem ended. Al-Janaideh and Mahadin (2015) also found that this allomorph was the last to be acquired by their students. At the other extreme, the current study revealed a preference to produce /iz/ correctly rather than producing $/ \mathrm{z} /$. Table 14 provides a comparison between both groups' production as far as the allomorph /iz/ is concerned.

Table 14

The production of /iz/ by both groups

\begin{tabular}{|c|c|c|c|c|c|c|c|c|c|c|}
\hline $\begin{array}{l}\text { First-Year } \\
\text { Students' } \\
\text { Production }\end{array}$ & flerch & feech & nuce & mace & trize & threeze & fladge & ladge & lish & frash \\
\hline $\begin{array}{l}\text { Number of incor- } \\
\text { rect productions }\end{array}$ & 29 & 21 & 7 & 14 & 23 & 14 & 30 & 28 & 16 & 14 \\
\hline $\begin{array}{l}\text { Percentage } \\
\text { incorrect }\end{array}$ & 58 & 42 & 14 & 28 & 46 & 28 & 60 & 56 & 32 & 28 \\
\hline Average incorrect & \multicolumn{2}{|c|}{50} & \multicolumn{2}{|c|}{21} & \multicolumn{2}{|c|}{37} & \multicolumn{2}{|c|}{58} & \multicolumn{2}{|c|}{30} \\
\hline $\begin{array}{l}\text { Percentage } \\
\text { correct }\end{array}$ & 42 & 58 & 86 & 72 & 54 & 72 & 40 & 44 & 68 & 72 \\
\hline Average correct & \multicolumn{2}{|c|}{50} & \multicolumn{2}{|c|}{79} & \multicolumn{2}{|c|}{63} & \multicolumn{2}{|c|}{42} & \multicolumn{2}{|c|}{70} \\
\hline $\begin{array}{l}\text { Fourth-Year } \\
\text { Students' } \\
\text { Production }\end{array}$ & flerch & feech & nuce & mace & trize & threeze & fladge & ladge & lish & frash \\
\hline $\begin{array}{l}\text { Number of incor- } \\
\text { rect productions }\end{array}$ & 9 & 5 & 6 & 6 & 10 & 9 & 8 & 9 & 7 & 5 \\
\hline $\begin{array}{l}\text { Percentage } \\
\text { incorrect }\end{array}$ & 18 & 10 & 12 & 12 & 20 & 18 & 16 & 18 & 14 & 10 \\
\hline Average incorrect & \multicolumn{2}{|c|}{14} & \multicolumn{2}{|c|}{12} & \multicolumn{2}{|c|}{19} & \multicolumn{2}{|c|}{17} & \multicolumn{2}{|c|}{12} \\
\hline $\begin{array}{l}\text { Percentage } \\
\text { correct }\end{array}$ & 82 & 90 & 88 & 88 & 80 & 82 & 84 & 82 & 86 & 90 \\
\hline Average correct & \multicolumn{2}{|c|}{86} & \multicolumn{2}{|c|}{88} & \multicolumn{2}{|c|}{81} & \multicolumn{2}{|c|}{83} & \multicolumn{2}{|c|}{88} \\
\hline
\end{tabular}


As can be inferred from Table 14, both groups scored the highest percentage correctly producing /iz/ in stems that end in $/ \mathrm{s} /$ and $/ \mathrm{sh} /$. Stems ending in $/ \mathrm{z} /$ came next in correct production by the first-year group, while stems ending in the voiceless palato-alveolar affricate / ch/ came next in correct production by the fourth-year students. The first-year students scored the lowest percentage of correct production of stems ending in the voiced palato-alveolar affricate / $\mathrm{dg} /$ sound. The fourth-year students scored the lowest percentage of correct production of stems ending in the $/ \mathrm{z} /$ sound.

Concerning the most preferred repair strategy, both groups showed a preference for replacing /iz/ with /is/. This indicates that all members of both groups are aware of the fact that these nonsense words are singular and to pluralize them they need to be inflected. That is why none of the students left a word without the plural morpheme. However, once again, first language interference is detected in the students' tendency to add /is/ instead of /iz/. As mentioned earlier, the Arabic language has the voiceless fricative phoneme whose phonological form is $/ \mathrm{s} /$ and has only one phonetic realization, [s].

\section{Conclusion and Recommendation}

This study aimed to investigate Jordanian university students' level of awareness of the morphophonemic nature of the English plural marker. Partial consistency was detected between findings in this study and findings of other studies in the literature. Discrepancies are reflected in the following four points.

First, there is a difference in the order of acquisition of the allomorphic variants of the regular plural marker. Subjects in this study tended to master the production of /s/ followed by /iz/, finally mastering /z/. In Berko's study (1958), /iz/ was acquired last. In Al-Janaideh and Mahadin's study (2015), /iz/ was also found to be acquired last.

Second, is reflected in the process of regressive assimilation. Subjects in this study tended to devoice final consonants to assimilate them with $/ \mathrm{s} /$, whereas, in Berko's (1958) study, subjects voiced final voiceless consonants to assimilate them with $/ \mathrm{z} /$. However, subjects' tendency to devoice final consonant to assimilate them with /s/ in this study is consistent with Peng and Ann's (2004) study.

Third, which makes the results of this study differ from others, is that younger subjects in this study had a greater tendency to use $/ \mathrm{s} /$ instead of $/ \mathrm{z} /$ compared with older subjects. Al-Janaideh and Mahadin's (2015) older subjects, on the other hand, tended to replace $/ \mathrm{s} /$ with $/ \mathrm{z} /$ more than the younger subjects did. 
Fourth, subjects in this study tended to use /is/ in place of /iz/. This form of replacement has not been attested in any of the previous research.

We hypothesize that the excessive use of /s/ instead of /z/ and /is/ instead of /iz/ resulted from first language transfer. Students were applying the phonotactics of Arabic to the English plural morpheme and to its various phonetic productions.

In order to enhance their students' awareness of the morphophonemic nature of the English plural morpheme, teachers are advised to draw the students' attention to this phenomenon directly. That is to say, teachers should teach this morpheme and its phonetic variables deductively. Now that the students are aware of the fact that they are learning English and are capable of realizing and understanding such complicated issues, there is no harm in pointing out the difference between the three phonetic variants of the plural morpheme explicitly and directly. Steinberg and Sciarini (2006) posit that older learners of a second language possess a cognitive capacity that enables them to think about, analyze and comprehend such abstract issues through explicative methods.

Additionally, instructors should draw their students' attention to the phonological rules that govern the distribution of the plural morpheme in English. In addition, instructors are encouraged to use the students' mother tongue as a facilitating factor by comparing and contrasting the status of the /s/ phoneme in both languages.

It is also recommended that research be conducted and an acoustic analysis carried out to test the authentic sound of [s] produced instead of [z]. In other words, acoustic analysis will yield results that are more accurate in terms of whether or not the students devoice the [z], notwithstanding the fact that Arabic speakers do not devoice final consonants in Arabic.

\section{References}

Al-Janaideh, R., \& Mahadin, R. (2015). The acquisition of the English plural morpheme and the regular past tense morpheme by Arabic-speaking students in Jordan. International Review of Social Sciences, 3(11), 512-534.

Allerton, D. (1979). Essentials of grammatical theory: A comparison view of syntax and morphology. London: Routledge and Kegan Paul.

Altarawneh, S. M., \& Hajjo, M. H. (2018). The acquisition of the English plural morphemes by Arabic-speaking EFL learners. International Journal of Education \& Literacy Studies, 6(2), 34-39. http://dx.doi.org/10.7575/aiac.ijels.v.6n.2p.34

Anthony, J., \& Francis, D. (2005). Development of phonological awareness. Current Directions in Psychological Science, 14(5), 255-259. https://doi.org/10.1111\%2Fj.0963-7214.2005.00376.x

Berko, J. (1958). The child's learning of English morphology. Word, 14(2-3), 150-177. (Published online December, 2015). https://doi.org/10.1080/00437956.1958.11659661 
Brown, R. (1973). A first language: The early stages. Cambridge, MA: Harvard University Press.

Bussmann, H. (2000). Routledge dictionary of language and linguistics. London: Taylor and Francis.

Carr, P. (2013). English phonetics and phonology: An introduction. Chichester, West Sussex: Wiley Blackwell.

Cazden, C. (1968). The acquisition of noun and verb inflections. Child Development, 39(2), 433-488. https://psycnet.apa.org/doi/10.2307/1126956

Kopcke, K.-M. (1998). The acquisition of plural marking in English and German revisited: Schemata versus rules. Journal of Child Language, 25(2), 293-319.

Natalicio, D., \& Natalicio, L. (1971). A comparative study of English pluralization by native and non-native English speakers. Child Development, 42(4), 1302-1306. https://doi.org/10.2307/1127817

Peng, L., \& Ann, J. (2004). Obstruent voicing and devoicing in the English of Cantonese speakers from Hong Kong. World Englishes, 23(4), 535-564. https://doi. org/10.1111/j.0083-2919. 2004.00376.x

Steinberg, D. D., \& Sciarini, N. V. (2006). An introduction to psycholinguistics. Abingdon, Oxon: Routledge.

Zeigler, J., \& Goswami, U. (2005). Reading acquisition. Developmental dyslexia and skilled reading across languages: A psycholinguistic grain size theory. Psychological Bulletin, 131(1), 3-29. https://doi.org/10.1037/0033-2909.131.1.3

Qadri Farid Tayeh, Hana Asaad Daana

\section{Das Bewusstsein des Vorhandenseins verschiedener phonetischer Varianten des englischen pluralbildenden Morphems unter Studenten der Universität von Jordanien}

\section{Zusammenfassung}

Im vorliegenden Artikel wird einer Analyse unterzogen, inwieweit die Studenten der Universität von Jordanien in der Fachrichtung Anglistik das Bewusstsein des Vorhandenseins verschiedener phonetischer Formen bzw. Varianten des englischen pluralbildenden Morphems haben. Die Analyse bezieht sich auf die Ergebnisse einer Umfrage, an der sich 50 Studentinnen des vierten Studienjahres und 50 Studentinnen des ersten Studienjahres an der Princess Alia University College, Al-Balqa Applied University Amman beteiligt haben. Den Teilnehmerinnen wurden Listen mit je 30 zufälligen einsilbigen Substantiven ohne Sinn zur Verfügung gestellt, um ihr Bewusstsein im Bereich verschiedener phonetischer Formen des englischen pluralbildenden Morphems zu prüfen. Dabei stellte es sich heraus, dass die Studentinnen des vierten Studienjahres bessere Ergebnisse hinsichtlich der Produktion von verschiedenen phonetischen Formen des englischen pluralbildenden Morphems erzielten als die Studentinnen des ersten Studienjahres. Die beiden Gruppen verwendeten dieselben Strategien in Bezug auf die Fehlerkorrektur und benutzten in ihren Antworten die Analogien zur Muttersprache.

Schlüsselwörter: pluralbildendes Morphem, phonologische Formen, phonetische Variante 
